\title{
Imagens em trânsito: as virgens de Luján e Sumampa e os circuitos coloniais na América Meridional na primeira metade do século XVII
}

\section{José Carlos Vilardaga ${ }^{2}$}

RESUMO: Neste artigo busca-se analisar a materialidade e parte da trajetória de duas imagens seiscentistas em terracota - uma de Nossa Senhora da Conceição e outra de Nossa Senhora da Consolação - que se tornaram, respectivamente, a Virgen de Luján, padroeira da Argentina, e a Virgen de Sumampa. Ambas são compreendidas aqui como entrelaçadas nas variadas redes e conexões estabelecidas entre a América portuguesa e espanhola, nos espaços contíguos da América Meridional na primeira metade do século XVII. No texto, discute-se uma possível procedência "paulista" dessas imagens, o que, para além de uma aparente casualidade, atesta como o grande "espaço peruano", articulado por Potosí, incluía também distintas regiões da América portuguesa. É nesse espaço ampliado, marcado pelo tráfego de pessoas, mercadorias e objetos atrelados às redes comerciais de contrabando, que acompanhamos os percursos dessas duas imagens, buscando visualizar como elas ganharam sentidos peculiares em ambientes e contextos diversos.

PALAVRAS-CHAVE: Virgem de Luján. Virgem de Sumampa. Circulação. Contrabando. América Meridional.

ABSTRACT: This article seeks to analyze the materiality and part of the trajectory of two seventeenth-century terracotta statuettes - one of Nossa Senhora da Conceição and another of Nossa Senhora da Consolação - who respectively became the Virgin of Luján, patron of Argentina, and Virgen of Sumampa. Both are understood here as intertwined in the various networks and connections between the Portuguese and Spanish America in the contiguous areas of South America in the first half of the seventeenth century. In the text, we discuss a possible "Paulista" origin of these images which, in addition to an apparent coincidence, attests that the great "Peruvian space," articulated by Potosí, also included distinct regions of Portuguese America. li is in this expanded space marked by the traffic of people, goods and objects linked to the networks of smuggling that we follow the paths of these two images, trying to visualize how they got peculiar meanings in different contexts and environments.

KEYWORDS: Virgin of Luján. Virgin Sumampa. Circulation. Smuggling. Meridional America.
1. Este texto faz parte da pesquisa Fluxos, intercâmbios e circulação na região platina-séculos XVI e XVII, desenvolvida com financiamento do $\mathrm{CNPq} /$ Universal (2014).

2. Doutor em História pela Universidade de São Paulo (USP). Professor no Departamento de História na EFLCH-Unifesp. E-mail: <jvilardaga@unifesp.br>. 
3. Utilizamos aqui o conceito de Monarquia Católica, e o processo de mundialização que o acompanha, conforme as definições de Serge Gruzinski (2014).

4. Ver Arjun Appadurai (2009).

5. Ver Igor Kopytoff (2009).
Introdução

Neste texto buscamos acompanhar parte da trajetória de dois objetos considerados sagrados - duas imagens da Virgem Maria - pelos caminhos coloniais da região platina na primeira metade do século XVII. Para além de sua óbvia - e necessária - compreensão como bens materiais, quer-se, sobretudo, analisar as circunstâncias e as personagens envolvidas no deslocamento dessas imagens até os locais onde elas se tornariam, ao longo dos anos, objetos de devoção. Nesse sentido, pretende-se conhecer um pouco mais dessa espécie de momento "inaugural" ao qual elas passaram a materializar o sagrado cristão em terras americanas; mas não para esclarecer qualquer "milagre", e sim para destrinchar o universo de circunstâncias envolvido no deslocamento dessas imagens.

Objetiva-se, sobretudo, articular e integrar uma bibliografia sobre a elaboração dessas peças à uma outra produção bibliográfica sobre as redes comerciais platinas e atlânticas do século XVII. Ao fazermos isso, pretendemos sobrepor a trajetória dessas imagens da Virgem nas rotas comerciais e humanas, legais e ilegais, do circuito econômico relacionado ao Rio da Prata, ampliando a compreensão sobre o leque de objetos que participaram do vasto cenário de circulação, nos espaços coloniais americanos, da chamada Monarquia Católica, centralizada na península lbérica entre fins do século XVI e meados do século $X V \|^{3}$.

Por fim, ainda à guisa de introdução, cabe ponderar que compreendemos os dois objetos em questão como bens materiais, relacionados a determinadas técnicas de produção, usos sociais e formas de aproveitamento de recursos ambientais específicos. Contudo, os objetos não produzem valor em si mesmos, de forma inerente, mas ganham sentido em sua circulação e trajetória por ambientes distintos 4 . Na busca desses elementos, tentamos elaborar uma "biografia" desses objetos, acompanhando parte de sua "vida social", em especial àquela que participa do deslocamento das imagens de seu local de produção até os assentamentos nos quais se fixaram ${ }^{5}$.

As imagens e os "milagres"

A primeira imagem, conhecida como a Pura y Limpia Concepcion de Luján, é uma representação de Nossa Senhora da Conceição (Figura 1), cuja devoção foi ratificada como a principal de Portugal por D. João IV, o primeiro da dinastia dos Bragança. A imagem é de terracota (barro cozido) e mede 38 centímetros. A Virgem aparece de pé sobre nuvens onde estão quatro cabeças de anjos. Em ambos os lados da figura há pontas da lua em quarto crescente. Possui o rosto oval e uma cor morena. A outra, conhecida como Virgem de Sumampa, é uma representação de Nossa Senhora da Consolação, com o menino Jesus nos braços (Figura 2). É menor que a de Luján, pois mede 23 centímetros. Na imagem, a Virgem senta-se sobre uma banqueta apoiada em um pequeno monte. 


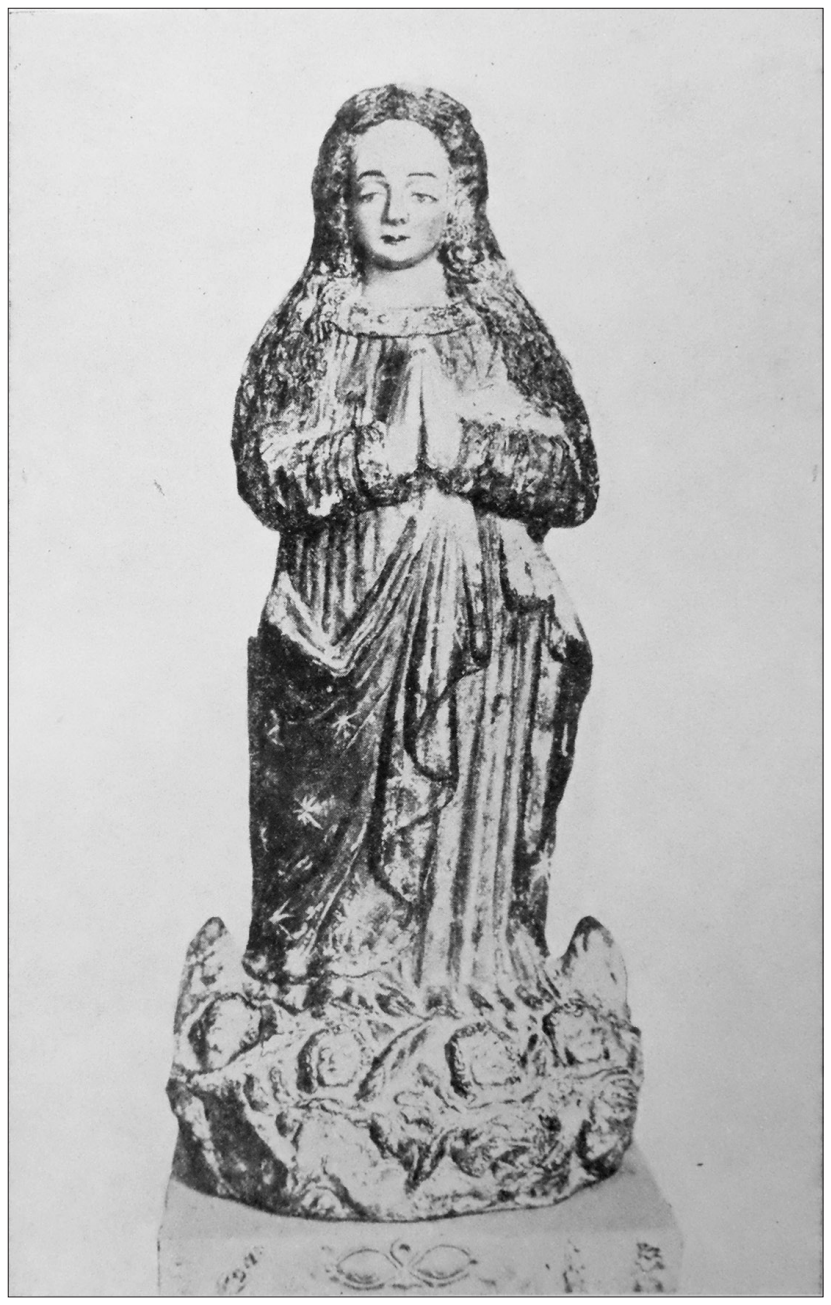

Figura 1 - Pura y Limpia Concepcion de Luján. Imagem extraída do livro de Juan Antonio Presas (1974). Foto de Carlos Lucero, anterior a 1915 .

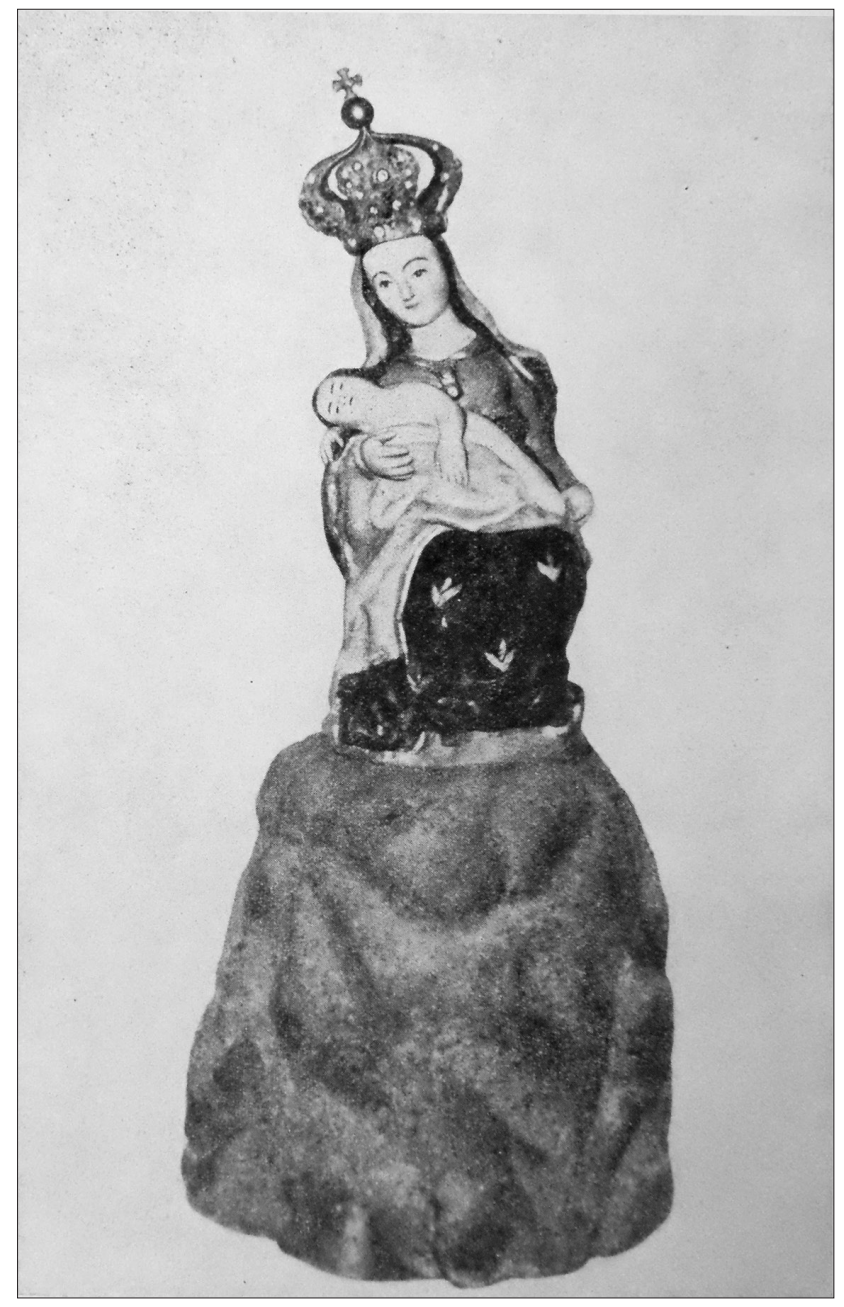

Figura 2 - Imagem extraída do livro de Juan Antonio Presas (1974). Foto de Espíndola Lucero.
Ambas foram produzidas com as mesmas técnicas e com a mesma argila, rica em material orgânico, mais esbranquiçada na origem e menos mineralizada, o que ressaltaria a cor escura das imagens depois da queima, que não precisa ser muito elevada. As duas possuem traços e formas bastante rústicos, tendo sido produzidas por algum artífice popular ou aprendiz. $\bigcirc$ cronista Jorge Salvaire, em 1885, dizia da imagem de Luján que "no es, debemos confessarlo (...) una obra de arte". Já sobre a de Sumampa, seu cronista Luiz Taboada dizia que: "el conjunto es un poco tosco y deficiente como obra de arte"b.

As duas imagens seguem o que se pode chamar de "cânones" em termos de produção desse tipo de imagem: simetria, verticalidade, estaticidade, leve sorriso aparentando serenidade, cabelos ondulados e compridos, túnica longa, peanha com querubins e volutas com nuvens ${ }^{7}$. Essas peças eram, muito
6. Cf. Juan Antonio Presas (1974).

7. Ver Ailton S. Alcântara (2008). 
8. Ver Juliana Beatriz Almeida de Souza (2001).

9. Ver Juliana Beatriz Almeida de Souza (2001) e José Lélio Mendes Ferreira (1992).

10. Cf. Luis Mott (1997, p. 159). Nas crônicas sobre o pedido de Farias de Sáa, conta-se que ele encomendou a imagem da virgem pois vivia na estância, apartado e distante da vila e, portanto, precisava construir uma capela para ouvir missa. Ver Juan Presas (1974)

11. A crônica mais antiga sobre a Virgem de Luján é de 1737, feita pelo mercedário Frei Pedro Nolasco de Santa Maria, El origen y milagros de la milagrosa imagen de Nuestra Señora de Luján, que a teria produzido a partir dos relatos dos próprios pais e da tradição oral. Alguns anos depois, em 1812 , veio à luz a crônica mais conhecida e detalhada sobre o tema, produzida pelo presbítero Felipe José Maqueda, Historia verídica del origen, fundacion $y$ progreso del Santuario de Nuestra Señora de Luján, baseada nos estudos do franciscano Antonio Oliver (1711-1787). Em 1857, Juan Maria Gutierrez, membro da chamada Generación de 1837 - grupo de jovens intelectuais argentinos de inspiração romântica e liberal -, escreveu sobre Luján num artigo intitulado Santuarios de America. Outra crônica importante foi a de José Maria Salvaire, Historia de Nuestra Señora de Luján, de 1885. O historiador Raul Molina também escreveu sobre o tema em 1967 Leyenda e bistoria de la Virgen de Luján e, mais recentemente, a principal referência tem sido o padre Juan Presas, que busca analisar os eventos que envolvem a Virgem de Luján sob uma perspectiva documental e histórica. provavelmente, produzidas em oficinas conventuais e cumpriam função importante na nova missionação surgida do Concílio de Trento (1545-1563). Serviam bem ao papel de recurso didático de evangelização e às práticas missionárias levadas a cabo por franciscanos, jesuítas e outras ordens regulares na América. Além do mais, a Virgem Maria tornou-se um dos símbolos da contrarreforma, assumindo proeminência em relação a outros santos; e sua capacidade de multiplicar representações sendo sempre o mesmo personagem the dava plasticidade para se fazer presente em inúmeras situações.

As imagens produzidas nesse contexto não eram, obviamente, restritas às diversas representações de Maria, mas a devoção mariana sem dúvida preponderou sobre outras figuras santas. Como veremos, as duas imagens em questão foram produzidas no Brasil - portanto colônia portuguesa -, e foram encomendadas por um português que vivia em Tucumã. Assim, vale ressaltar que a devoção à Maria foi a preferencial de Portugal, que tinha reservado a ela 17 festas em seu calendário e a escolheu como padroeira. A presença da imagem de Maria esteve presente desde os primórdios da colonização em terras lusas, pois foi embarcada na armada de Cabral, assim como esteve na armada de Vasco da Gama quando este se dirigiu à Índia. Dava nome a embarcações e nomeou as primeiras capelas em solo brasileiro ${ }^{8}$. Ademais, a imagem da Virgem cedo se associou, na América como um todo, às figuras marginalizadas do processo de conquista e colonização, pois fazia ressaltar seu lado piedoso, protetor e acolhedor, o que parecia, à primeira vista, amenizar a violência da conquista. As formas mestiças de suas representações permitiam uma maior penetração de seu culto junto às populações indígenas, negras e mestiças da América?.

Essas imagens, produzidas em barro ou madeira, tinham tamanhos variados, e poderiam tanto ser colocadas em templos e capelas quanto servir a devoções privadas, no interior das residências, em oratórios ou nichos. De fato, estiveram presentes tanto em rituais públicos, como procissões, missas, novenas e romarias, em que funcionavam como um "contrapeso socializador significativo para compensar a dispersão espacial e o isolamento social" do mundo colonial, quanto em capelas privadas, mais segregadas ${ }^{10}$. Podiam, em alguns casos, servir a interesses mais práticos. No mundo platino, por exemplo, ter uma imagem católica na estância configurava mantê-la ocupada e povoada, uma boa forma de se conseguir as recorrentes, e desejadas, licenças concedidas pelo cabildo de Buenos Aires para a caça do gado cimarrón (accioneros), solto nos pampas.

A respeito das duas imagens consolidou-se uma certa tradição religiosa que narra os fatos envolvidos na chegada delas ao Rio da Prata, bem como aos "milagres" envolvidos em sua singularização. Por meio desta tradição, temos a notícia de que no ano de 1630, por volta do mês de maio, duas imagens em terracota da Virgem Maria - uma de Nossa Senhora da Conceição e outra de Nossa Senhora da Consolação - desembarcaram no porto de Buenos Aires ${ }^{1}$. Trazidas por um marinheiro lusitano de nome Andrea Juan, na embarcação San Andres, eram parte de uma encomenda feita pelo estancieiro português, Antonio 
Farias de Sáa. Este era hacendado em Sumampa, mais ou menos no meio do caminho entre Córdoba e Santiago del Estero, num dos ramais do chamado Camino Viejo, e teria encomendado as imagens junto a um "amigo" do Brasil. Sáa queria construir uma capela para abrigar as virgens e exaltar sua devoção mariana. As imagens teriam ficado retidas, como parte de um carregamento de contrabando, na Real Audiência da cidade platina. Além de outras cargas, fazia companhia às imagens um negro escravo de nome Manoel, também ele, muito provavelmente, clandestino e retido como carga ilegal.

Depois do pagamento da fiança feito pelo rico proprietário de estâncias Don Rosendo de Oramas, Andrea Juan, a carga e o escravo embarcaram numa longa viagem terrestre, nas carretas que percorriam o Camino Viejo para Potosí e que passavam pela província de Tucumã. Depois de dois dias de viagem, a caravana parou nas terras de Rosendo, nas cercanias de Luján, para o pouso rotineiro. No dia seguinte, ao tentar retomar a viagem, a carreta não se moveu. Tudo se tentou, mas foi inútil. Algumas mercadorias eram descarregadas para aliviar o peso e nada dos bois retomarem seu caminho. Somente quando a caixa que continha uma das santas foi desembarcada é que finalmente a carreta se deslocou. Testou-se, sob o olhar incrédulo dos presentes, recolocar a caixa e novamente a carreta estancou. Retirou-se e ela andou. Ficou claro a todos que a imagem da Virgem - a da Conceição - queria ali permanecer. Desembarcada a imagem, que coincidentemente ficou nas terras dos Rosendo sob os providenciais cuidados do negro Manoel, a caravana retomou seu rumo até Córdoba, onde parte das mercadorias foi colocada sobre os lombos de algumas mulas para o seguimento da viagem.

Em Sumampa, próximo a Santiago del Estero, a mula que levava em seu lombo o peso leve da segunda Virgem e se dirigia às terras de Sáa desgarrouse do comboio e caminhou sozinha até a uma localidade onde empacou. De novo, não havia maneira de mover o animal. A vontade da Virgem - agora a da Consolação - impôs-se novamente, e ali mesmo ela ficou. Farias de Sáa, resignado, mandou construir uma capela naquele local, de taipa e palha, o que foi feito, segundo as crônicas religiosas, por índios Abipones evangelizados. A igrejinha, depois melhorada, ainda está de pé, abrigando a imagem da padroeira de Santiago del Estero e dos viajantes, a Virgem de Sumampa. Quanto à imagem estacionada em Luján, esta teve um destino ainda mais glorioso. Conhecida como Virgen estanciera ou Patroncita morena, ganhou uma primeira ermida, pobrezinha, nas terras de Rosendo, na margem esquerda do rio Luján, em 1633. O lugar se tornou ponto de devoção. Em 1674, uma rica estancieira viúva, de nome Ana de Matos, desejou transladar a imagem até suas terras, na margem direita do mesmo rio Luján e convenceu os herdeiros das vantagens. Ana prometia a construção de uma capela e uma infraestrutura para o acolhimento dos peregrinos. Translado feito, no dia seguinte a imagem reapareceu na velha ermida, sob os cuidados do sempre zeloso escravo Manoel, agora já idoso. Somente com a bênção do bispo e com uma procissão oficial, acompanhada pelo mesmo Manoel, a imagem aceitou se 
12. Ver Guillermo Furlong (1969).

13. As crônicas mais antigas apenas referenciam uma importação vinda do Brasil. $O$ fato de a embarcação de Andrés Juan ter vindo de Pernambuco é que fortaleceu a hipótese de uma origem pernambucana. Ver Juan Presas (1974).

14. Ver Carlos Lemos (1979).

15. Ver Carlos Lemos (1999).

16. Ver Eduardo Etzel (1971).

17. Cf. Percival Tirapeli (2003).

18. Ver Dom Clemente Maria da Silva-Nigra (1971). aquietar na sua nova morada. De capela o lugar cresceu, virou centro de romaria, ganhou basílica e, em 1930, o papa Pio XI declarou a "pura y limpia Concepcion de Luján" como a padroeira da Argentina, Uruguai e Paraguai.

A origem brasílica

De modo geral, pouco se especulou sobre a origem brasílica das imagens. Nega-se que elas possam ter sido feitas na própria região platina, já que não há registro algum desse tipo de produção ali'12. O fato de a tradição ressaltar uma importação pernambucana pareceu resolver a fonte local dessas representações ${ }^{13}$. Entretanto, os estudiosos da produção desse tipo de imagem em terras coloniais da América portuguesa, de modo geral, recusam uma origem pernambucana, iá que a capitania não produziu imagens em terracota ${ }^{14}$.

Alguns estudos das décadas de 1970 e 1980 começaram a sugerir que as imagens pudessem ter sido produzidas nas imediações de São Paulo de Piratininga. Segundo Carlos Lemos, existiam duas áreas produtoras dessas imagens em terracota no contexto colonial, e ambas associadas à produção em mosteiros beneditinos: Bahia e São Paulo. Nesses locais, forjou-se uma tradição na feitura dessas peças de devoção que se espalharam por várias partes da colônia. $\bigcirc$ uso da terracota, prática adaptativa de origem indígena dessa produção em terras brasileiras, foi um traço distintivo de uma "escola" de produção dessas imagens ${ }^{15}$. No caso de São Paulo, teria forjado as chamadas "paulistinhas", imagens de terracota, bastante rústicas, precariamente cromadas, e que se pautavam em cópias de cópias. Anônimas, teriam idealmente um modelo provavelmente europeu que se perdia nas duplicações e reproduções feitas por freis artífices ou aprendizes de todo tipo, inclusive indígenas aldeados e catecúmenos ${ }^{16}$.

Segundo Percival Tirapeli, foi na Capitania de São Vicente que surgiu a chamada "imaginária brasileira"17, nascida das mãos de um português, que cumpria pena na vila de São Vicente, e que esculpiu uma Nossa Senhora da Conceição e uma Nossa Senhora do Rosário, ambas em barro cozido policromado. João Gonçalo Fernandes é assim reconhecido como um dos pioneiros nessa produção de imagens santas no Brasil. De todo modo, o fortalecimento dessa produção de São Paulo é atestado pela presença, nos mosteiros de São Bento nas vilas de São Paulo, Santana de Parnaíba e Santos, do frei Agostinho de Jesus (c. 1600-166 1). O fluminense Agostinho teria aprendido sua técnica com o mestre português, e também frei beneditino, Agostinho da Piedade, na Bahia. Acredita-se que Agostinho de Jesus estudou em Portugal na década de 1620 e retornou à Bahia em 1634. Não se sabe exatamente quando se transferiu para as capitanias do Sul, mas parece seguro afirmar que produziv em São Paulo nos anos de 16401650. Há suspeitas de que ele tenha sido o escultor da Nossa Senhora de Aparecida, encontrada em 1717, nas águas do rio Paraíba, e que se tornaria a Padroeira do Brasil ${ }^{18}$. Já se especulou se as imagens das virgens em território argentino não seriam elas também de sua autoria. Além de não coincidir em termos 
de datas, já que Agostinho de Jesus só teria produzido em São Paulo a partir da década de 1640, as imagens são muito mais rústicas e não seguem bem o estilo do mestre beneditino. Carlos Lemos, que se debruçou sobre a análise das imagens e sua origem, principalmente a partir de estudos de fotografias, acredita que elas foram produzidas com o barro da várzea do rio Tietê, numa das possíveis oficinas de Santana de Parnaíba ou de alguma freguesia das margens do rio ${ }^{19}$. Ele defende que as imagens argentinas são de alguma "tradição popularesca vicentina", e não de um grande mestre do ofício; e que elas seguem um "padrão paulista" - embora mais rústico que o depois inaugurado por Agostinho de Jesus -, que seguia determinados padrões de altura, posição hierática, representação dos cabelos, uma certa imprecisão das cabecinhas e a ausência de volutas. Dessa opinião também compartilha Aracy Amaral - ao reproduzir o parecer de Lemos -, que concorda com a provável origem vicentina das imagens, mas não acredita que sejam de Agostinho de Jesus, pois são muito mais rústicas ${ }^{20}$. De qualquer forma, tudo leva a crer que a argila que produziu a Virgem de Luján, a de Sumampa, e até mesmo a de Nossa Senhora Aparecida, no Brasil - esta última com 39 centímetros e também de terracota - seja a mesma. A fonte: as margens do rio Tietê, nas proximidades da vila de São Paulo de Piratininga, na Capitania de São Vicente, nas partes do Brasil21.

Ao encamparmos a hipótese da origem vicentina das imagens, algumas ponderações devem ser feitas. Elas parecem acompanhar uma sociedade que teve, no movimento, nas andanças pelo sertão e caminhos interiores, uma de suas principais formas de organização ${ }^{22}$. Além disso, São Paulo foi marcada por uma população possuidora de hábitos compósitos, mestiços, da qual a solução da terracota demonstra uma adaptação, com os recursos locais, aos padrões e técnicas de representação que vinham da Europa ${ }^{23}$. Por fim, a rusticidade das imagens, visíveis na rigidez da postura, na policromia de qualidade limitada, nas desproporções e nos panejamentos que desafiavam as leis da gravidade, são bem afeitas a uma sociedade marcada pelo improviso e por uma certa precariedade.

\section{Conexões}

De todo modo, a se confirmar esta origem "paulista" das imagens platinas, deve-se reforçar que a presença delas em espaços tão distantes não foi uma excepcionalidade. Apesar das principais rotas marítimas que conectavam Buenos Aires ao litoral do Brasil passarem principalmente pelo Rio de Janeiro, Bahia e Pernambuco, portos nos quais grande parte dos envolvidos em contrabando mantinha agentes comerciais, a vila de São Vicente - e, por conseguinte, a vila de São Paulo, sua complementaridade no planalto - foram também um ponto importante de parada e abastecimento dos navios e armadas que demandavam os Mares do Sul e também os portos africanos ${ }^{24}$. $\bigcirc$ porto abastecia de farinhas, arroz, gado e marmeladas, provenientes do planalto, as embarcações estacionadas. Além disso, ao longo das últimas décadas do século XVI e as primeiras do XVII,
19. Ver Carlos Lemos (1979).

20. Ver Aracy Amaral (1981).

21. Outro autor que sugere a origem paulista é Francisco Roberto (1978).

22. Ver Sérgio Buarque de Holanda (1994).

23. Ver Carlos Lemos (1999).

24. Ver Alice P. Canabrava (1984). 
25. A produção econômica da Capitania de São Vicente entre o final do século XVI e a primeira metade do século XVII está muito bem apresentada e discutida em John Manuel Monteiro (1998)

26. Ver Carlos Sempat Assadourian (1966).

27. Ver Manuel Eufrásio de Azevedo Marques (1980).

28. Cf. Inventários $e$ testamentos (v. 44).

29. Ver Jorge Caldeira (2006), apud Carlos Sempat Assadourian (1965).

30. Ver Alice Canabrava (1984, p. 123). Marie Helmer (1953), que estudou o comércio de Potosí com a Bahia no século XVI, também aponta o intenso crescimento desse comércio com Buenos Aires no final do século, coincidindo com o governo de D. Francisco. somaram-se aos produtos elencados o ferro e o algodão, além de uma boa quantidade de trigo produzida nas imediações da vila de São Paulo entre as décadas de 1610-1640. De São Vicente partia ainda uma quantia expressiva de açúcar produzida na sua pioneira zona de engenhos, sendo alguns de propriedade de comerciantes flamengos ${ }^{25}$

Carlos Assadourian, em sua investigação sobre as companhias de comércio negreiro de Córdoba, mostra como numa prestação de contas de um socio viajero, que foi a Angola comprar escravos, registra-se a permanência do navio por sete meses em São Vicente, onde chegou a alugar um imóvel e comprar mantimentos tanto para si (porco e vinho), quanto para os escravos (milho, farinha de mandioca e carne $)^{26}$.

As relações deste porto e de sua hinterland paulista com a região de Buenos Aires foi, de fato, também precoce. Foi um dos pontos de parada e abastecimento escolhido pelo bispo mercador Francisco de Vitória, que ali estacionou algumas vezes para comprar açúcar e conservas na década de 1580. Em 1592, ao ser nomeado capitão da vila de São Paulo, que enfrentava dura guerra contra os índios que sitiavam o núcleo urbano, Afonso Sardinha resolveu fazer seu testamento. Nele, o tanoeiro de origem demonstrou ser detentor de razoável riqueza e ter muitas conexões e relações comerciais. Possuía navios aprestados para Angola, bens em Santos, negócios e empréstimos no Rio de Janeiro e Bahia $^{27}$. Sardinha negociava escravos da Guiné, tecidos, marmelada e gentios, e possuía um trapiche de açúcar. Mas o que chama a atenção em seu testamento é certo trato que manteve em Buenos Aires. Ali, Sardinha tinha com Antonio Rodrigues de Barros uma sociedade, e nela acertou-se o recebimento de lã e peles da região platina, e o envio de três índios tupis, marmelada, duas varas de renda, nove bainhas de facas da Alemanha, 14 mãos de papel e uma botija de água rosada. De produtos da terra a bens europeus, Sardinha parecia participar desse interessante e rentável tráfico com Buenos Aires. Além de Sardinha, Antonio Pedroso de Alvarenga, já em 1643, elenca entre suas pendências comerciais por ocasião do testamento "quinhentas varas de pano" enviadas ao capitão Domingos Correa, do Rio de Janeiro, para serem vendidas em Buenos Aires, que "em vilas castelhanas darão seis sentos e tantas". Indagava-se, contudo, sobre o destino da mercadoria, pois "neste tempo com aclamação de S Magestade cessou o comercio e se fechou aquele porto" 28 .

A presença do governador geral do Brasil, D. Francisco de Souza, em São Paulo, entre 1599-1604 e 1609-161 1, acentuou esse tráfico. Souza construiu assíduas relações com Buenos Aires desde quando tomou posse de seu cargo em Salvador. Em Tucumán, no ano de 1593, o português Manuel Pereira assinou um contrato de venda de quatro escravos negros para serem negociados em Potosí, e nele aparecia como procurador de D. Francisco de Souza ${ }^{29}$. Para Canabrava, esse comércio com o Rio da Prata permitiu a entrada de 500.000 cruzados no Brasil exatamente no governo de D. Francisco ${ }^{30}$. Deve-se ressaltar que os primeiros anos do governo de Souza na Bahia coincidem com uma das últimas passagens do 
bispo de Tucumán, D. Francisco de Vitória, pela cidade de Salvador. Fica claro que o governador foi um apoiador dessas redes de relações comerciais entre a costa do Brasil e o espaço peruano, e isso explicaria porque Hernando de Vargas, o primeiro contador nomeado para o Rio da Prata e estacionado acidentalmente em Salvador, ter escrito uma entusiasmada carta para sua irmã contando como "un cabalero governador qui si llama Don Francisco de Souza qui hace me tanta merce... dando me dineros y con tanta voluntad como si yo fuera su heredero..." 31

Já em São Paulo, em 1600, o governador enviou mercadorias ao porto platino sob o pretexto de obter recursos para construir fortalezas. Na sua segunda passagem pela vila vicentina, como governador da recém-criada Repartição Sul, trouxe uma autorização para importar do Rio da Prata sementes de trigo, cevada e até lhamas para o transporte do ouro que ele prometia extrair na Capitania ${ }^{32}$. Um de seus engenheiros, Baccio de Fillicaya, trazido para ajudar a tonar viável esse projeto mineral na vila paulista, acabou se deslocando para Buenos Aires, onde chega em 1611 , tornando-se comerciante e construtor, interferindo nas obras do cabildo e do forte da vila portenha ${ }^{33}$.

Por fim, alguns moradores da Capitania de São Vicente tinham relações mais estáveis com Buenos Aires. A influente família Barreto tinha um filho, Roque, capitão da Capitania de São Vicente; outro, Nicolau, foi um dos primeiros líderes de bandeira, e que chegou ao Guairá em 1602-03; e Francisco Barreto, que andava por Buenos Aires em 1599. Ali serviu de testemunha num processo movido pelo governador Dom Diego de Valdez y Banda contra um morador de São Vicente - Cristóvão de Aguiar - que andava traficando índios em terras do atual estado de Santa Catarina ${ }^{34}$. João Maciel, "homem bom" da vila de São Paulo, tinha um sobrinho na vila portenha: Melchior Maciel, natural de Viana, que esteve em Santa Fé e depois se instalou em Buenos Aires, onde se casou com Catarina Cabral de Melo. Foi negociante de açúcar, barcos e comprou terras em Madaglena, onde passou a produzir o chamado Vino de La Costa ou Vino Patero. Maciel era, portanto, mais dos muitos portugueses - originários do reino português ou de alguma parte do Brasil - estabelecidos em Buenos Aires ${ }^{35}$. Quase a totalidade do trabalho em prata e ourivesaria em Buenos Aires era feito por portugueses ${ }^{36}$; assim como o trabalho com móveis, feito quase inteiramente em madeira brasileira, especialmente o jacarandá, trazida nesse fluxo comercial constante ${ }^{37}$.

A presença de portugueses de São Paulo na região do Prata não se restringia a Buenos Aires. Maria da Graça Ventura localizou em Santiago del Estero um português natural de São Paulo, Antonio de Brito, carpinteiro, que teria entrado por Buenos Aires, sem licença, em 160338. Em Santa Fé, Salvador de los Reyes, natural da inusitada - e desaparecida - vila vicentina de São Felipe, aparece entre os recenseados portugueses em $1643^{39}$. Além disso, é famoso o caso de Antonio Castanho da Silva, morador de Santana de Parnaíba, que morreu em Potosí por volta de $1620^{40}$.

Parece-nos óbvio que os maiores beneficiários desse tráfico e intercâmbio com Buenos Aires e com o "espaço peruano" fossem Bahia, Pernambuco e Rio de
31. Cf. José Carlos Vilardaga (2014, p. 160).

32. Ver Roseli Santaella Stella (1999).

33. Ver Raúl Molina (2000)

34. Ver José Carlos Vilardaga (2014).

35. Ver José Gonçalves Salvador (1978). Ricardo de Lafuente Machain (1931) chegou a contabilizar, em 1643, 108 moradores portugueses em Buenos Aires.

36. Ver Maria José Goulão (1990).

37. Ver Sara Bomchil \& Virginia Carreño (2011, tomo I).

38. Ver Maria da Graça Ventura (2005)

39. Ver Luis María Calvo (1999, p. 410).

40. Ver Inventários e Testamentos (v. 36). 
41. Cf. José Carlos Vilardaga (2014, p. 249, nota 737).

42. Ver Charles Boxer (1973).

43. Ver Juan Antonio Presas (1974, 2002). Presas reconstitui a árvore genealógica dos Sáa em Sumampa e chega ao protagonista dessa história. Sugere, ainda, que Sáa era um português oriundo do Brasil que entrou por Buenos Aires por volta de 1615. Depois de se instalar em Córdoba, onde tornou-se vecino, teria se filiado à família de Pedro de Villalba, um dos fundadores da cidade.

44. Eram vários os locais em que se faziam a troca das carretas puxadas por bois pelas mulas: Santiago del Estero era um deles, mas isso também podia ser feito em localidades mais próximas às cordilheiras, como Salta e Jujuy. O principal centro criador de mulas era Córdoba, de onde elas eram vendidas ainda jovens para Estero, Salta e Jujuy, e ali eram criadas por mais alguns anos até que estivessem prontas para efetuar os percursos montanhosos rumo à Potosi. Acarette du Biscay (2014) fala em 30 mil animais vendidos por ano.

45. Cf. Zacarias Moutoukias (1988, p. 57).

46. Chamamo-lo aqui de misterioso pois pouco se conhece sobre ele, além das pistas deixadas no próprio relato, sobre o qual ainda pesam algumas dúvidas, já que a primeira edição, em francês, de 1672, desapareceu, e as outras edições, tanto em francês quanto em inglês, sofreram alterações. A primeira edição em castelhano é da segunda metade do século XIX, vertida de uma edição inglesa do final do século XVII. Dentre as passagens nas quais ele localiza
Janeiro, locais em que atuavam uma das famílias pioneiras desses tratos: os Sá. Salvador Correia de Sá chegou a ser reconhecido inclusive pelo vice-rei de Portugal, Cardeal Alberto, que mandou "agradecer a Salvador Correa capitão do Rio de Janeiro ser o primeiro que abriu este caminho"41. As conexões dos Sá com o mundo platino são bastante conhecidas, mas vale lembrar aqui que Salvador Correia de Sá e Benevides, neto do primeiro, esteve cinco anos no Paraguai, casou-se com uma criolla rica de Tucumã chamada Catalina Ugarte de Velazco e ganhou os repartimientos de índios de Filipa, Laqueme, Paqui e Lingasta, todas ainda em Tucumã, em $1636^{42}$.

Assim, cabe reforçar que a Capitania de São Vicente e a vila de São Paulo participaram, mesmo que em menor escala, dessas transações comerciais e intercâmbios que conectaram espaços econômicos, movimentaram mercadorias, mas também promoveram fluxos de pessoas, objetos e práticas na América Meridional.

\section{Comércio, contrabando e redes}

Para compreendermos o trajeto das imagens desde a suas origens até o interior da Província do Rio da Prata, devemos analisar alguns dos personagens dessa trama meio fantástica com mais vagar. Devemos, sobretudo, partir da premissa de que a presença dessas peças originárias de terras brasílicas em espaços platinos nada teve de surpreendente. Muito pelo contrário, fizeram parte de uma extensa rede de circulação comercial - legal e ilegal -, em grande parte tocada por portugueses estabelecidos nos caminhos marítimos e terrestres que conectavam a costa brasileira ao Rio da Prata e a Potosí (Figura 3).

primeiro que analisamos é o estancieiro Antonio Farias de Sáa, que teria sido o responsável pela encomenda das imagens. De origem portuguesa, Sáa possuía estância em Sumampa, conforme investigação em documentação local feita pelo padre Juan Antonio Presas ${ }^{43}$. A localidade pertencia à jurisdição de Santiago del Estero, e Sáa era vecino de Córdoba. Ela ficava na passagem de um dos ramais do caminho entre Córdoba e Potosí, ponto a partir do qual muitas vezes se fazia a troca das tradicionais carretas pelo lombo de mulas ${ }^{44}$. Antonio Farias, sobre quem não há muitas informações adicionais, era, muito provavelmente, um desses personagens da "diáspora" portuguesa espalhados pela América espanhola. $\bigcirc$ fenômeno da presença marcante de portugueses na América sob domínio de Espanha é nitidamente anterior ao período da União Ibérica (1580-1640), como bem demonstra a presença de inúmeros deles entre as tripulações dos navios castelhanos e entre os contingentes de conquistadores e povoadores ao longo de praticamente todo o século XVI. Como afirmou Zacarias Moutoukias, "por más importante que haya sido, la unión de las coronas ibéricas no explica, por si sola, la amplitud del fenômeno que, por ló demás, es anterior" 45 . E posterior, como revela o relato do misterioso viajante Acarette du Biscay, que ao percorrer o caminho, em 1658, identificou portugueses estabelecidos em diversos locais ${ }^{46}$. 


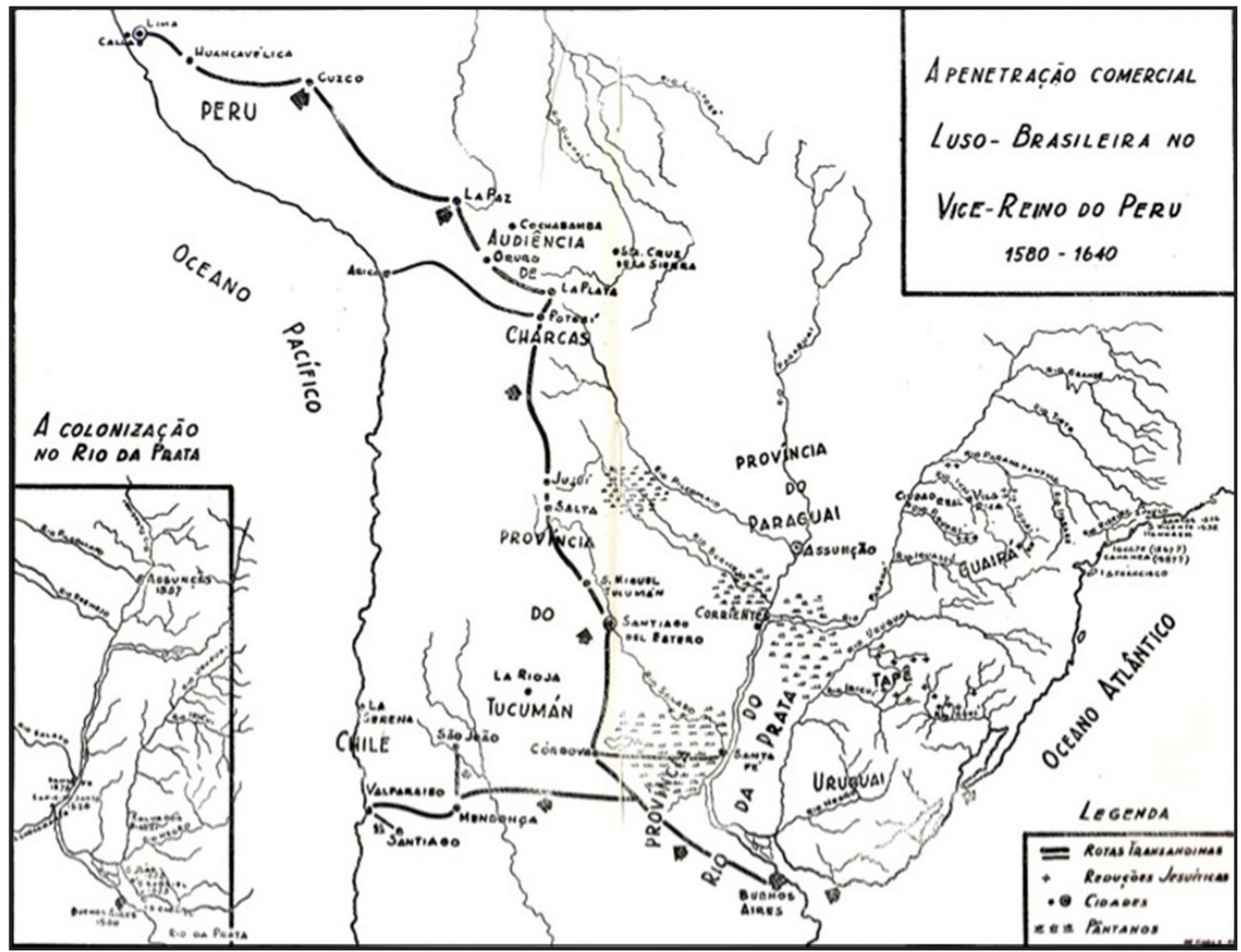

Figura 3 - Mapa extraído do livro de Alice Canabrava (1984, p. 184-185).

Mas se o confuso período jurisdicional da união das coroas não explica por si só, ajuda a reforçar e intensificar o processo. Nesse contexto, a presença de portugueses nas rotas comerciais foi facilitada pela retórica da vassalagem comum "ao rei de Espanha" e pela fluidez nas fronteiras e limites territoriais, legais e cotidianos. Paradoxalmente, as constantes proibições, perseguições e desconfianças do império espanhol em relação aos portugueses - bem como o fato de os lusos nunca terem sido considerados "naturais" no seio da monarquia filipina ${ }^{47}$ - foram acompanhadas, na maior parte das vezes, pela aceitação e incorporação cotidiana desses portugueses nas vilas, cidades, portos e rotas da América espanhola ${ }^{48}$.

Dentre os espaços nos quais os portugueses se instalaram prontamente estava a rota Buenos Aires - Potosí. A descoberta do centro minerador no Alto Peru, em 1545, organizou a economia colonial de grande parte da América Meridional. Em pouco tempo, uma série de vilas, aldeias, haciendas, estâncias e espaços produtivos articularam-se no sentido de complementar a economia local potosina que crescia em torno da exploração da prata, incrementada de modo acentuado a partir da organização da mão de obra indígena, sob o sistema da mita, pelo vice-rei Francisco de Toledo (1569-1581) e pela introdução do processo de amálgama da prata, a partir da década de 1560. Ao longo da segunda metade do século XVI, Lima assumiu o controle sobre grande parte dos negócios que portugueses, cito aqui o trecho entre o rio Saladillo e Córdoba, onde ele encontra "casas de campo habitada por los espanoles, los portugueses y los nativos...” Cf. Acarette du Biscay (2014, p. 60).

47. O tema da identidade portuguesa no contexto da monarquia hispânica é bastante controverso. As ampliações de autorização para entrada de estrangeiros na América nunca abarcaram os portugueses. Em cédula de 1596, por exemplo, eram considerados estrangeiros todos os que não fossem de Castela, Leão, Aragão, Valência, Catalunha, Navarra e ilhas Maiorca e Minorca. No século XVII, no Peru, os portugueses eram um dos poucos grupos de "estrangeiros" que pagavam o imposto da composion, que napolitanos, flamengos e sicilianos, por exemplo, que faziam - como os portugueses - parte do grande império espanhol, eram isentos. De fato, a própria definição de quem eram os "espanhóis", recuperando a antiga Hispânia ibérica, foi amplamente debatida num contexto do qual claramente se castelhanizava a Espanha, e essas definições participavam de um amplo projeto imperial. Para uma discussão mais aprofundada sobre isso, ver Maria da Graça Ventura (2005, v. I e II); Tamar Herzog (2003) e Pedro Cardim (2010).

48. O trabalho de Maria da Graça Ventura (2005) busca abranger o Vice-Reino do Peru como um todo, mas a presença de portugueses, especialmente no Rio da Prata, tem sido explorada pela historiografia há muito tempo. A obra pioneira é de Ricardo de Lafuente Machain (1931); mas há trabalhos para outras regiões, como o de Augustin Zapata Gollán (1970); ou o de Carlos R. Jensen (2007). 
49. Ver Carlos Sempat Assadourian (1983).

50. Cf. Maria da Graça Ventura (2005, p. 45).

51. Ver Frei Reginaldo de Lizarraga (1916).

52. Buenos Aires foi ganhando cada vez mais importância como porta de entrada e saída de mercadorias, apesar das regulações da Coroa e das eventuais perseguições aos contrabandistas. $\mathrm{O}$ primeiro cerceamento veio por meio de uma cédula real em 1594, que permitia aos moradores fazerem comércio apenas com a Espanha, por Sevilha e com licença especial. Em 1602, nova cédula concedia aos vecinos proprietários de navios que exportassem, por 6 anos, uma quantidade limitada de farinha, couro, sebo e carne e trouxessem alguns artigos necessários que não poderiam ser revendidos para fora de Buenos Aires. As licenças temporárias foram renovadas algumas vezes $\mathrm{e}$ construíam um pretexto, na brecha de legalidade, para comercializar produtos clandestinamente. Já em 1603, por exemplo, o tenente de governador de Buenos Aires vendia licenças comerciais para portugueses, que prontamente assumiram papel de destaque nesse comércio legal e ilegal na cidade portenha. Ver Macarena Perusset (2006); Rodrigo Ceballos (2008) e Zacarias Moutoukias (1988).

53. Cf. Carlos Assadourian (1983). O chamado "espaço peruano" pode ser definido como "todo el inmenso território que la mineria altoperuana fue creando a su alrededor como polo de atracción y ordenamiento regional. Durante los siglos XVI y XVII, éste abarcaba el território que se extendía desde Quito hasta el envolviam o fluxo de metais e o abastecimento das minas. Isso porque a imposição do modelo de frotas e porto único oficializou a rota que ligava os portos de Nombre de Díos a Callao ${ }^{49}$.

A segunda fundação de Buenos Aires, em 1580, na boca platina do Atlântico, cumpriu, a priori, funções atreladas aos interesses de Assunção, centro da Província do Paraguai e Rio da Prata e dos núcleos de povoamento ao longo da bacia platina. Contudo, já em 1587, o senso de oportunidade do bispo de Tucumã, o padre dominicano português Francisco de Vitória, abriu um horizonte novo aos interessados na prata peruana. $O$ bispo, que fora comerciante no Peru, comprou do Brasil, via Buenos Aires, produtos como conservas, açúcar e outras mercadorias, que revendeu no Chile em 1583. Em 1585, armou um navio para comerciar em terras brasileiras. Já em 1587, o governador de Tucumã, Juan Ramirez de Velazco, presenciou que o bispo, "cuja vida não é de prelado senão de mercador", aparelhou 30 carretas carregadas de "lã, sombreros, frazadas, mantas, telas de algodon, cordobanes" e, claro, a desejável prata ${ }^{50}$. No retorno, trouxe escravos negros e manufaturas, além de produtos vindos das partes do Brasil, como arroz, açúcar, marmeladas e ferro. Tal pompa, e circunstância, foi tão marcante que o dia do embarque, dois de setembro, tornou-se, por uma daquelas ironias do destino, o Dia da Indústria Argentina. $O$ personagem Vitória ficou marcado, sobretudo, por essas iniciativas comerciais nem sempre ortodoxas, e sobre ele sempre pairou um clima de escândalo, além das suspeitas de ser cristão novo. Por outro lado, um companheiro seu de noviciado, o dominicano Reginaldo de Lizárraga, fez questão de defendê-lo em seu relato sobre o Rio de Prata, alegando que a fortuna do docto bispo havia sido feito loablemente ${ }^{51}$.

De qualquer maneira, depois da estreia, Buenos Aires passou a cumprir um papel importante no comércio e tráfico coloniais, mesmo que as proibições, as licenças somente temporárias e a perseguição sistemática das elites mercantis de Lima tentassem colocar um freio na rota atlântica ${ }^{52}$. Buenos Aires tornou-se peçachave no que Carlos Assadourian chamou de "espaço peruano", um amplo território articulado pela prata potosina e todas as atividades comerciais a ela relacionadas ${ }^{53}$. Ao longo das décadas seguintes, muita mercadoria entrou e saiu pelo porto e, grande parte dela, de maneira ilegal. Mas se a rota Buenos Aires - Potosí pressupunha uma conexão direta entre o centro minerador e o comércio atlântico, conectando, por outros meios, Potosí ao comércio internacional, Zacarias Moutoukias, em trabalho clássico, mostrou com extrema competência os entrelaçamentos internos, o comércio inter-regional e local que se estruturou a partir da rota platina ${ }^{54}$.

Ao longo de seus diversos trechos e ramais, um comércio de excedentes, trocas internas, de abastecimento regional e mesmo de manutenção dos próprios caminhos permitiu uma sucessão de negócios e intercâmbios comerciais que tornou ainda mais complexo um circuito que ultrapassou em muito a simples ligação direta entre o núcleo mineiro e o porto atlântico. $\bigcirc$ autor, dentre os inúmeros estudos de caso que apresenta, comenta como comerciantes portugueses traziam ferro e 
açúcar do Brasil até Tucumã, onde trocavam por produtos locais que depois seriam novamente trocados em Potosí pela valorizada prata. Esse comércio inter-regional, que alimentou e construiu algumas fortunas, foi também um lugar privilegiado para ação de portugueses. Segundo Ventura:

Foi na rota Buenos Aires - Potosí que os portugueses se ligaram à propriedade fundiária e se promoveram socialmente como encomenderos, ainda nos finais do século XVI. A dinâmica comercial do Potosi incitava-os a praticar uma economia mista, mas era sua ligação a aristocracia local, através do casamento com filhas e netas de conquistadores, ou pela obtenção de mercês, que suportava a sua ascenção socia| ${ }^{55}$

Foi nela que, associando-se à prática do comércio e tornando-se, eles mesmos, produtores - não se deve imaginar essa separação - os portugueses procuravam estabelecer-se e fixar-se nos espaços comerciais da América espanhola. E, nesse processo, legitimaram-se muitas vezes como vecinos por meio de casamentos com descendentes de povoadores espanhóis. Lafuente Machain revelou esta prática no porto de Buenos Aires, mas ela fica evidente em outras regiões, inclusive no ramal paraguaio do caminho, como em Santa Fé, onde Augustin Zapata Gollán também desvendou essa estratégia ${ }^{56}$.

No caminho em questão, a Província de Tucumã demonstrou manifesta dependência em relação a Potosí desde finais do século XVI, e a produção de algodão foi uma das atividades que dominou a estrutura econômica da região. Nela, a cidade de Santiago del Estero, fundada em 1553, tornou-se um importante espaço de concentração das oficinas (obrajes) que processavam o algodão regional tucumenho. $O$ próprio cronista Lizárraga comenta como, ao lado da criação das mulas que abasteciam o comércio potosino, os tecidos de Santiago del Estero eram uma das atividades mais promissoras daqueles territórios ${ }^{57}$. Com o tempo, o grosso desse mercado sofreria alguns contratempos, mas uma produção de cunho regional sempre se manteve forte ${ }^{58}$.

Alguns desses produtores eram portugueses, que cumpriam o papel de produtores-comerciantes. Segundo Ventura:

O tipo social comum a ambas regiões, no que respeita à atividade mercantil, o produtor comerciante, é representado na figura do encomendero que monopoliza parte substancial da mão de obra indígena e se envolve nas trocas comerciais, participando directamente no mercado ou vendendo a sua produção agrícola, ganadeira ou industrial a mercadores especializados ${ }^{59}$

Muito provavelmente, este era o caso de Farias de Sáa, já que, como estancieiro português, morador de Córdoba e proprietário em Sumampa, mantinha contatos comerciais com um marinheiro português a quem encomendou as imagens da Virgem. Além disso, usou de índios "convertidos" para o erguimento da capela que abrigou uma das peças, o que o coloca diretamente na condição de encomendero. E, de fato, não estava sozinho. Conforme levantamento feito por Graça Ventura, somente em Córdoba, somando residentes e estantes, havia 30
Paraguay”. Cf. Raúl Fradkin \& Juan Carlos Garavaglia (2009, p. 41)

54. Ver Zacarias Moutoukias (1988). As articulações regionais no Paraguai, proporcionadas pela ampla economia alto-peruana, foi também tema de excelente estudo de Juan Carlos Garavaglia (2008).

55. Cf. Maria da Graça Ventura (2005, p. 179-180)

56. Ver Augustin Zapata Gollán (1970). Griselda Tarragó e Nidia Areces afirmam que "el casamiento de la mayoria de los portugueses con hijas $y$ nietos de conquistadores en Buenos Aires es un viejo procedimento de arraigo de los contrabandistas". (1999, p.176).

57. Reginaldo de Lizárraga fala de muito tecido em Santiago del Estero (riqueza de la tierra), e "tan ancho como Holanda, uno más delgado que otro y cantidad de pavillo, medias de puncto, alpargatas, sobrecamas e sobremesas, y otras cosas por las cuales de Potosi les traen reales". (1916, p. 235).

58. Apesar da concorrência de tecidos peruanos, os têxteis tucumenhos de algodão continuaram a ser uma das grandes riquezas regionais e principal meio de troca nas relações entre pueblos indígenas e entre índios e encomenderos.Ver Raúl Fradkin \& Juan Carlos Garavaglia (2009).

59. Cf. Maria da Graça Ventura (2005, p. 35-36) 
60. Ver Maria da Graça Ventura (2005).

61. Diego Lopes de Lisboa pertencia à rede de contrabandistas encabeçada pelo sevilhano Juan de Vergara e pelo português Diego de Vega, ambos a partir de Buenos Aires.

62. Ver Zacarias Moutoukias (1988). Estero, conhecida como "madre de ciudades" por ter sido base de fundação de várias outras, foi capital da Província de Tucumã até a mudança para Córdoba, na década de 1620.

63. Ver Carlos Sempat Assadourian (1966). Para esse autor, os escravos eram a mercadoria de maior importância que circulava pela rota, e Córdoba estava especialmente bem situada, no entroncamento dos caminhos que conectavam Buenos Aires, Potosi, Paraguai e Chile.

64. Cf. Rodolfo González Lebrero (2002, p. 71).

65. Cf. Alice Canabrava (1984, p. 109).

66. Ver Zacarias Moutoukias (1988, 2000) portugueses entre os cerca de 300 vecinos que viviam na cidade por volta de 1622. Em Santiago del Estero eles eram 24. Na província de Tucumã, em 1607, viviam 124 estrangeiros, sendo 109 os portugueses ${ }^{60}$.

Córdoba - onde Sáa era vecino - era um ponto nevrálgico da rota Buenos Aires - Potosí e tornara-se, sob o controle de comerciantes-proprietários, muitos deles portugueses, ponto de distribuição das mercadorias europeias. As mercadorias eram trocadas pelos panos produzidos na região, em especial em Santiago del Estero, e também pelas mulas, criadas ali. Além disso, a cidade era também um centro de distribuição de escravos negros, no qual chegou a atuar um dos nomes mais afamados dentre os contrabandistas lusitanos de todo o espaço peruano: Diogo Lopes de Lisboa ${ }^{61}$. Moutoukias considerou Córdoba o lugar mais importante de todo o percurso, e seu complemento, Santiago del Estero, 115 léguas mais ao norte, era, por outro lado, a passagem mais difícil de toda a travessia, em especial nos tempos de chuvas ${ }^{62}$.

Em Córdoba, segundo estudo empreendido por Carlos Assadourian, organizavam-se companhias de comércio - algumas exclusivamente de comércio negreiro - que associavam comerciantes, proprietários de navios e carretas. Juntava encomenderos e comerciantes com um "associado viajante" que, de modo geral, era uma função ocupada por um português ${ }^{63}$. Esse comércio movimentava, no fluxo contínuo de ambas as direções, escravos, panos, mercadorias europeias, prata, farinhas, sebo, couro e tantas outras mercadorias. Para o Brasil, principalmente para Pernambuco, Salvador e Rio de Janeiro, portos principais desse comércio de "cabotagem" que se instalou nas costas atlânticas da América Meridional, transportava-se prata, farinhas, carnes salgadas, sebo, couros e os chamados "artículos del interior", aí incluindo os panos de Tucumã. Do Brasil, em contrapartida, vinham escravos negros, açúcar, vinhos, sal, madeiras e móveis, cal, telhas, ladrilhos e azulejos 64 .

De todo modo, esse comércio amplo, e que envolvia várias regiões, companhias comerciais e produtores, personagens e logísticas, passou por aquilo que já foi chamado de "racionalização" do contrabando, mudando "da fase empírica, do século XVI, das atividades isoladas, para um período de racionalização no século XVII, caracterizado pela coordenação das atividades de elementos diversos agindo em áreas geográficas diferentes" 65 . As primeiras décadas do século XVII foram de estruturação das redes comerciais - legais e ilegais -, e de afirmação desses novos grupos junto às instâncias de poder locais e regionais. Essas redes, ancoradas em relações clientelares e parentais, abarcavam amplos territórios e uma multiplicidade de personagens, de relações de dependência e reciprocidade, e uma infinidade de mercadorias. Neste caso, tinham amplitude transatlântica e transregionalob. Em Buenos Aires, foi marcante o conflito entre os chamados "beneméritos", pioneiros da povoação e, de modo geral, estancieros; e os "confederados", adventícios, dentre eles muitos portugueses, que se ocuparam do comércio e do contrabando. Aos poucos este último grupo assumiu o poder e o comando da cidade, controlando os cargos no cabildo e impondo suas políticas 
junto aos governadores enviados de Madrib7. $\bigcirc$ ano que nos diz respeito diretamente, o de 1630, é exemplar para demonstrar a força desses grupos. $\bigcirc$ governador da Província do Rio da Prata era D. Francisco de Céspedes 11624 16311 , que foi inicialmente bem recebido e acolhido pelos setores comerciais de Buenos Aires, mas os ânimos em relação a ele mudaram radicalmente a partir de 1627. Nesse ano ele começou uma perseguição sistemática ao contrabando e chegou a levar o poderoso líder dos contrabandistas, Juan de Vergara, à prisão. Este foi resgatado pelo seu irmão, bispo, e uma campanha contra o governador obrigou Céspedes a fugir de Buenos Aires e procurar a ajuda do idoso exgovernador Hernando Arias de Saavedra. Céspedes conseguiu ainda arrastar o seu governo por mais algum tempo, mas logo acabou substituído68.

$\bigcirc$ poder destas redes comerciais de contrabando sofreu algumas oscilações ao longo do século XVII. Para Alice Canabrava, é inegável que há uma primeira queda dos níveis do comércio na região na década de 1620. Ela teria sido o resultado de uma conjunção de fatores, como a instauração da Alfandega de Córdoba, em 1623, que atrapalhou a naturalidade dos negócios e obrigou muitos a refazerem suas rotas e reconstruírem suas relações; a presença portuguesa na região platina, que foi cada vez mais criticada, pois era vista como uma ponta de lança de interesses flamengos e judaicos; os ataques sistemáticos dos portugueses de São Paulo aos espaços guairenhos; e, por fim, a queda sensível na produção da prata potosina ${ }^{69}$. Moutoukias, por outro lado, apesar de reconhecer igualmente a queda de volume desse comércio internacional, e compreender os motivos apontados por Canabrava, acredita que assim mesmo a rota continuou a movimentar expressivo tráfico local e inter-regional70. Percebe-se que, em geral, apesar dos contratempos as redes comerciais foram continuamente se fortalecendo e se ajustando a diferentes conjunturas ${ }^{71}$.

As imagens encomendadas por Farias de Sáa se conectaram com essas grandes redes comerciais organizadas a partir de Buenos Aires por meio de um dos personagens envolvidos no périplo das peças. Lembremos que somente uma delas chegou ao seu destino. A outra estacionou - milagrosamente, dizem as crônicas - nas terras de Don Rosendo de Oramas, na região próxima ao rio Luján. $\bigcirc$ que sabemos desse personagem? Na verdade, Bernabé Gonzales Filiano Oranas nasceu em 1585, em Tenerife, nas ilhas Canárias. Chegou a Buenos Aires em 1614, em embarcação onde foram encontrados 30 escravos negros clandestinos. Na vila portenha, rapidamente se atrelou ao grupo de comerciantesestancieros-contrabandistas liderados por Juan de Vergara. Em 1622, Bernabé casou-se com Francisca de Trigueiros Enciso, que tivera uma irmã - já falecida naquela altura - casada com Vergara. De todo modo, o poderoso Vergara foi padrinho de casamento e arcou com o rico dote da noiva. Francisca era bisneta por linha materna do conquistador do Paraguai, Domingos de Irala, e viúva de um tal de Tomás de Rosende.

Bernabé envolveu-se com o tráfico negreiro, e adquiriu estâncias ao longo do rio Luján, no chamado Camino Viejo e rota de circulação das carretas e
67. Ver Jorge Daniel Gelman (1985).

68. Ver Macarena Perusset (2006).

69. Ver Alice Canabrava (1984).

70. Cf. Zacarias Moutoukias (1988).

71. Na década de 1650 , por exemplo, marcada pelo conflito luso-castelhano resultante da "restauração portuguesa", o viajante Acarette du Biscay (2014) narra que a elite estancieira de Buenos Aires era muito rica, mas que a verdadeira fortuna do porto estava mesmo nas mãos dos comerciantes de produtos europeus. É curioso notar como o comércio com Brasil não tem mais nenhum destaque no seu relato, mas sim a ampla presença de navios flamengos e franceses no porto. A própria "restauração", vivida inicialmente com apreensão, foi aos poucos absorvida pelas redes de comércio, muitas delas ainda com ampla presença de portugueses. Ver Rodrigo Ceballos (2014). 
72. Ver Raul Molina (2000).

73. Ver Carlos Federico Ibarguren Aguirre (1977).

74. Ver Juan Presas (1974).

75. Ver Zacarias Moutoukias (1988). Novamente podemos exemplificar nos remetendo aqui ao relato de Acarette, que narra como no seu retorno de Potosí, carregado de prata, embarcou clandestinamente grande quantidade dela num barco ancorado num rio localizado mais para o interior.

76. Ver Juan Presas (1974). Os testamentos estão no Archivo General de la Nación. Sala IX, 4831-6/39 e 4832-7/618 de mercadorias legais e ilegais ${ }^{72}$. Ali explorou também o gado cimarrón. A estância que ficou conhecida como Rosendo Oramas fora comprada por Filiano junto a Juan Velázquez e Juan Vázquez. Bernabé chegou a ser procurador do cabildo de Buenos Aires, numa época em que o conselho municipal esteve nas mãos de Juan de Vergara, que o controlava completamente, já que comprara, em 1617, todos os seis cargos disponíveis. De fato, a instituição capitular de Buenos Aires ficou sob controle dos Vergara até o final da década de 1630.

A sogra de Bernabé faleceu em 1630 e foi enterrada na capela de Nossa Senhora da Limpia Concepcion, na igreja de São Francisco, local onde também seria enterrada a esposa Francisca. Portanto, a devoção à "Límpia Concepcion" pela família Rosendo Oramas parece bem anterior à "milagrosa" parada da virgem naquelas terras. Oramas faleceu em 1641 e legou uma rica casa em Buenos Aires, peças de prata lavrada, móveis em jacarandá, e várias estâncias ao longo do rio Luján com muitas cabeças de gado ${ }^{73}$.

As relações entre Farias de Sáa, Filiano Oramas e o piloto Andrea Juan se não podem ser consideradas evidentes, são bastante sugestivas. Elas configurariam uma das tantas redes comerciais que uniam as diversas pontas do sistema e dos caminhos platinos. Um piloto de nome Andrea Juan estava em Buenos Aires em junho de 1629, de onde partiu para Pernambuco. Ainda conforme as pesquisas de Juan Presas, ele voltou à vila em 23 de março de 1630, pilotando o navio San Andres ${ }^{74}$. Era uma pequena embarcação, entre 20 a 50 toneladas, como era a maioria das que faziam o comércio com o Brasil. Os pilotos eram em sua maioria portugueses que frequentavam regularmente o porto e conheciam comerciantes com quem, muitas vezes, associavam-se. Traziam alguns poucos escravos, e pequenas quantidades de ferro, açúcar, tecidos, móveis, ladrilhos e outros objetos, como as aparentemente inusitadas imagens sacras. Muitas dessas embarcações, inclusive, não paravam em Buenos Aires. Como mostrou Moutoukias, algumas delas ancoravam nos inúmeros deques que existiam ao longo dos rios Luján e Las Conchas, e que serviam às estâncias localizadas no Camino Viejo ${ }^{75}$.

Andrea Juan teve afiançada sua carga, inclusive seu escravo, por Filiano Oramas, de quem era muito provavelmente amigo. Presas analisa dois testamentos do piloto português, feitos em Buenos Aires respectivamente em 1631 e 1637. No primeiro, ele chega a legar seus bens ao próprio Filiano; já no segundo, os lega aos seus filhos e esposa. Vale ressaltar, contudo, que Juan faleceu em 1637 na residência portenha de Filiano, o que mostra os vínculos entre ambos ${ }^{76}$.

Cabe, por fim, ponderar sobre as possíveis funções e conveniências das imagens aos proprietários. Não é arriscado dizer que Bernabé Filiano Oramas, adventício que fora, preso por contrabando e que teve seu cargo de regidor no cabildo contestado em 1625, ter buscado uma legitimação como vecino casado com filha de conquistador - portanto accionero autorizado a caçar gado -, depois que herdou uma boa fortuna, inclusive estâncias e escravos negros, por ocasião da morte de sua sogra, em 1630, mesmo ano da chegada da Virgem às suas terras. A construção de uma capela era uma das formas de 
assentar-se como estanciero, e a imagem que ornaria a capela foi efetivamente providenciada.

No caso de Sumampa, vale ressaltar a pressão que recaiu sobre os portugueses - como Farias de Sáa - a partir da década de 1620, quando a Inquisição, instalada em Lima, passou a vigiar e apertar o cerco sobre esses lusitanos sempre suspeitos de práticas judaizantes. A manutenção de uma capela católica, sob inspiração da Virgem Maria, bem poderia cumprir também funções apaziguadoras e insuspeitas ${ }^{77}$.

Temos, portanto, um piloto português associado, no comércio com o Brasil, a um rico comerciante, estancieiro e contrabandista de Buenos Aires atrelado ao poderoso grupo de Juan de Vergara. Estes seriam filiados a um estancieiro português, com encomienda em Santiago del Estero, e bem estabelecido no ponto nevrálgico da rota Buenos Aires - Potosí, Córdoba, onde era vecino. Assim, desvela-se uma poderosa rede que envolve relações de parentesco e clientelismos, e que atrela espaços transatlânticos e transregionais. As representações da Virgem participam, assim, dessa ampla e bem estruturada rede de relações políticas e comerciais no espaço platino.

escravo Manoel e o traslado de Luján

A trajetória das imagens, em especial a de Luján, teve ainda um acompanhante quase sempre presente. É um escravo negro que a tradição nomeou por Manoel. Sabendo que uma das mercadorias mais cobiçadas nesse imenso mercado que se formou em torno do espaço peruano eram os escravos negros, não surpreende a presença de um desses acompanhando os passos da Virgem da Concepcion até Luján. Calcula-se, por baixo, que até 1645 entraram em Buenos Aires cerca de 30.000 escravos. Parte deles legalizados pelos asientos, contratos que concediam a comerciantes portugueses o embarque e revenda de uma quantidade determinada de escravos negros no porto de Buenos Aires ${ }^{78}$. Este tornara-se, já em 1615, um dos principais centros de redistribuição de escravos negros entrados, em sua maior parte, de maneira ilegal pelas arribadas forçadas de navios ${ }^{79}$. Somente em Córdoba existiam pelo menos seis companhias de comércio negreiro que armavam navios para o Brasil e Angola em busca de escravos e, ao longo do tempo, a imensa maioria deles era comprada diretamente no Brasil, em especial na Bahia, mas também em Pernambuco e Rio de Janeiro ${ }^{80}$.

Quando a carga do navio San Andres foi retida na Real Audiência, foi necessária a intervenção de Rosendo, que pagou a fiança para liberar a mercadoria. A liberação envolveu Manoel Costa de los Rios, como ficou conhecido, que era muito provavelmente de origem iorubá, e teria sido vendido como escravo em Cabo Verde. Ele deveria contar com cerca de vinte e poucos anos, aproximadamente, na altura do "milagre" 81 . Manoel foi um personagem profundamente associado à imagem da Virgem e ao processo de sua veneração. A ele coube o cuidado da primeira ermida, nas terras de Rosendo. Alguns anos
77. Ver Maria da Graça Ventura (2005).

78. Ver Rodolfo Lebrero (2002).

79. Ver Jean-Arsène Yao (2011).

80. Ver Carlos Sempat Assadourian (1966).

81. Novamente nos reportamos aqui ao padre Juan Presas (1974).

Conforme seu levantamento documental, um contrato de venda do escravo Manoel, feito em 1674 , revela sua origem cabo-verdense e idade. 
82. Ver Juan Antonio Presas (1990).

83. Ver Rubén Vargas Ugarte (1956).

84. Ver Juan Antonio Presas (1990). depois, quando a imagem foi transladada para outra propriedade, ele acompanhou a mudança e teria cuidado dela, e de sua capela, até o fim de sua vida ${ }^{82}$.

A imagem da Virgem de Luján, associada ao negro escravo, assim como a de Sumampa aos índios convertidos, reforçam a filiação da devoção da virgem à alguns dos personagens mais remediados do processo de colonização da América. Os exemplos de aparições de Nossa Senhora a índios, negros e mestizos são múltiplos na América colonial. Desde o famoso caso inaugural da Guadalupe mexicana, passando pela Nossa Senhora de Caacupê, que em 1600 teria aparecido a um guarani convertido no Paraguai; a Nossa Senhora de Copacabana, de 1550, que se revelou ao inca Francisco Tito Yupanqui; e a Nossa Senhora de Coramatá, atrelada à conversão do cacique Coronato, na Venezuela, em 1652. No caso do Brasil, temos a Nossa Senhora Aparecida, já no século XVIII, que tem sua imagem encontrada por três humildes pescadores provavelmente mestiços - nas águas do rio Paraíba do Sul83. $\bigcirc$ "desejo" que a Virgem apresentou de permanecer ao lado do negro Manoel, reforçando a associação dela à causa dos pobres e marginalizados, é explicitado no episódio do translado para a nova capela, quando a imagem teria voltado sozinha para a pequena ermida anterior. No caso de Sumampa, por outro lado, a imagem servirá, na década de 1690, para acompanhar as entradas que buscavam punir os índios Mocovies "rebelados", pactuando ao lado de uma das parcialidades, a dos indígenas convertidos.

A imagem de Luján sofreria, como já apontado, uma migração na década de 1670. A estância dos Rosendo andava decadente e meio abandonada naqueles anos, o que permitia somente uma precária devoção da Virgem, que, por outro lado, crescia em popularidade. Foi nessa ocasião que uma viúva, de nome Ana de Matos, convenceu o filho de Filiano Oramas, o jesuíta Juan de Oramas, a aceitar a mudança da virgem em troca de 200 pesos e a promessa de erguer uma capela. Ana de Matos é também uma personagem das mais interessantes. Natural de Córdoba, nascida em 1615, seu pai era açoreano e a mãe descendente dos primeiros povoadores daquela cidade. Era, portanto, ela mesma o resultado daquelas legitimações que os portugueses promoviam por meio de casamentos com descendentes de conquistadores. A família mudou-se para Buenos Aires em 1622. Em pouco tempo a vida de Ana viraria do avesso, já que perdeu pai e mãe num intervalo muito curto de tempo. Casou-se aos 15 anos com Marcos de Sequeira, um andaluz que já circulara pela Nova Espanha, Oruro, Potosí, Córdoba e finalmente Buenos Aires. Sequeira foi um rico estancieiro, e comprou as terras em Luján com quase sete mil cabeças de gado e centenas de ovelhas e cavalos. A fazenda ainda tinha 12 escravos negros. Ana tornou-se viúva em 1640, e pouco tempo depois se enamorou de Tomás de Rojas Acevedo, onze anos mais jovem que ela. Nunca se casaram, mas tiveram três filhos, o que a deve ter lançado no perigoso mundo da maledicência ${ }^{84}$. Tomás era filho de um dos homens mais poderosos de Buenos Aires, Pedro de Rojas y Acevedo, que chegou a assumir interinamente o governo da Província em 1641, por ocasião da morte do 
governador titular, Dom Ventura de Muxica; e de Dona Maria Vega, nada mais nada menos que a filha do português Diego de Vega, um dos mais importantes contrabandistas de Buenos Aires e sócio de Juan de Vergara. A dupla Vergara-Vega controlou o contrabando portenho por décadas, e chegou a desafiar a fúria do governador Hernando Arias de Saavedra que, por motivos eles próprios suspeitos, tentou desarticular a rede contrabandista. Tomás tinha um irmão, João Roxas de Azevedo, que estudou em Coimbra e foi secretário do rei de Portugal, D. Pedro II. As redes dos Acevedo chegavam ao núcleo da coroa portuguesa ${ }^{85}$.

A decadência das terras de Rosendo, por outro lado, não era fortuita. Elas ficavam nas margens de um dos primeiros ramais do Camino Viejo, cada vez mais abandonado, desde que em 1663 o cabildo recomendou uma mudança no traçado exatamente na altura de Luján ${ }^{86}$. Em compensação, as terras de Ana de Matos ficavam nas franjas do novo traçado, ou Camino Real, oficializado naquela década de 1660. Essa "coincidente" associação da Virgem às terras prósperas da viúva e amante de contrabandistas Ana de Matos, bem localizadas no novo caminho, era uma excelente oportunidade. Juan Gutierrez, ainda em 1837, lembrou ironicamente do oportunismo da situação criada com a instalação de um santuário e pulpería naquela estância ganadeira: "las vacas de la virgen fueron prodigiosamente fecundas" 87 .

Ao longo do caminho

Resta-nos, agora, compreender um pouco melhor o caminho que ligava Buenos Aires a Potosí, trajeto que as imagens viajaram rumo aos seus locais de assentamento. Em verdade, não era muito mais que um caminho instável e mutante e, como brilhantemente já se salientou, nele o "saber, hombres y medios de transporte constituian, entonces, la tecnologia mestiza que aseguraba la circulacion"88. Essa circulação podia ser feita, a cavalo, em pouco mais de 60 dias; ou nas famosas carretas, meio usual de circulação na rota entre Buenos Aires e Estero. Dali, as cargas eram transportadas em lombos de mulas rumo aos altiplanos, "que es el modo ordinário de transporte para passar las montañas que dividen el Peru de Tucumã"89.

A rota completa atravessava pouco mais de 2000 quilômetros, e passava por diversos pueblos indígenas, pequenas vilas e algumas cidades um pouco maiores. Percorria territórios da Província do Rio da Prata, Tucumã e, por fim, do Alto Peru. Um ramal de Córdoba conectava-se com a Província do Paraguai, subindo por Santa Fé, Corrientes e Assunção. Outro deslocava-se rumo ao Chile passando por Mendoza. Em destaque na rota para Potosí, as cidades de Buenos Aires, Córdoba, Santiago del Estero, São Miguel de Tucumã, Nossa Senhora de Esteco (mais tarde abandonada), Salta e Jujuy, de onde se subia para os altiplanos rumo à cidade mineira.

caminho percorria longos trechos desabitados, conforme indicam os relatos de alguns viajantes que o fizeram no século XVII, e as intermináveis llanuras
85. Ver Rodrigo Ceballos. (2014).

86. Ver Juan Presas (1974).

87. Cf. Jorge Juan Cortabarría (2007, p. 402).

88. Cf. Zacarias Moutoukias (1988, p. 21).

89. Cf. Acarette du Biscay (2014, p. 89). 
90. Ver Reginaldo de Lizárraga (1916). O relato do frei é de 1603, mas provavelmente reúne anotações dispersas de duas viagens, uma por volta de 1589 e outra no começo do XVII. No roteiro entre Esteco e Córdoba, afirma que "no viemos sino cielo y llanuras"; e de Córdoba a Buenos Aires, "en todas estas léguas no vi cosa digna de notar".

91. Cf. Acarette du Biscay (2014, p. 62).

92. Tanto Lizárraga quanto Acarette se impressionaram demais com avestruzes e com a quantidade de gado solto nos campos.

93. O termo Diaguita parece representar uma categoria colonial, agrupando aos olhares dos colonizadores e missionários espanhóis, distintos grupos que habitavam os Valles Calchaquies, como os próprios Diaguitas e Calchaquiés, e os Tafis, Quilmes e Tilcaras, por exemplo. De todo modo, esses grupos formaram alianças confederadas para resistir e negociar com os espanhóis. deveriam gerar alguma monotonia. Lizárraga afirmava que fez o percurso de Buenos Aires a Córdoba, quase 700 quilômetros, e não teve nada digno de notar. Alegava não ter visto sequer um arbusto 90 .

Além das extensas planícies pampeanas, ao longo do trajeło atravessavamse rios, alguns quase intransponíveis em épocas de chuvas; regiões montanhosas nas proximidades da Cordilheira e alguns vales férteis nos quais muitas vezes se instalavam as cidades. Das proximidades de Buenos Aires até os Arrecifes eram diversas e variadas as estâncias à beira do caminho. Muitas delas tinham uma de suas faces voltadas à rota, e outra voltada a rios como Luján e Las Conchas. Nestas, muitas vezes, existiam pequenos ancoradouros para embarque e desembarque clandestino de mercadorias. A estância de Oramas era uma dessas.

Estâncias, chácaras e pequenos pueblos eram encontrados aqui e ali, e serviam para abrigar os viajantes e forneciam-thes alimentos e informações. Entre o rio Saladillo e Córdoba, Acarette fala de várias plantações e casas de campo, mas entre Córdoba e Santiago, ressalta que encontrara apenas algumas casas isoladas onde "espanoles y portugueses quienen viven muy solitários" 91 . Conforme Lizárraga, ao longo do caminho prevaleciam, além de plantações de trigo, algodão e cevada, árvores frutíferas, como os pessegueiros e outras como as algarrobos (alfarrobeiras), com a qual se fazia uma chicha; os palo sanctum, usados no tratamento do mal francês, ou sífilis; e as lechetreznas, arbusto de planta tóxica da qual se extraia um látex usado como antisséptico. Aos viajantes impressionava a quantidade de gado solto, veados, felinos de diversos tipos, cobras e as avestruzes, caçadas com galgos ${ }^{92}$.

Os relatos dos viajantes que usamos aqui são também ótimas referências para perceber a presença das populações indígenas ao longo do caminho. Os índios aparecem relacionados à presença colonial de diversas formas: ora como proprietários de chácaras ao longo de partes do caminho, ou consumidos pelos maus-tratos e pela bebida; ora como caçadores de veados e gado, "salteadores", e negociantes de mercadorias locais. Poucas vezes aparecem como insubmissos, como no caso dos indígenas dos Valles Calchaquíes. Sabemos, por outro lado, que nesta primeira metade do século XVII, a proporção de índios efetivamente reduzidos na região era muito pequena, sendo restrita aos que viviam nos entornos das cidades espanholas e dos caminhos. Os habitantes dos extensos Valles Calchaquies, chamados genericamente de Diaguitas, eram, exatamente, os que mais frontalmente desafiavam os invasores espanhóis, causando fortes tensões junto às populações espanholas de Salta, Jujuy - estas duas fundadas exatamente para erguer uma barreira contra aqueles índios -, San Miguel de Tucumã, Esteco e Santiago del Estero - aí incluído Sumampa ${ }^{93}$. Constantemente em revolta ao longo da segunda metade do século XVI, grande parte da população foi encomendada apenas nominalmente ao longo desses anos e o clima de insatisfação entre os índios era permanente. Em meados de julho de 1630, mesmo ano da chegada das imagens ao porto de Buenos Aires e da instalação de uma delas em Sumampa, eclodiu uma grande revolta dos indígenas Calchaquíes que duraria até 1643. 
Liderada pelo cacique Chelemin, ela chegou a forçar o abandono da cidade espanhola de Londres. Uma nova revolta, praticamente uma guerra, tomou forma novamente entre 1657 e 1665, esta última liderada pelo aventureiro mestiço, o "falso inca" Pedro Bohorquez".

As carretas que trilhavam esses trajetos eram, em sua maioria, produzidas em Tucumã, onde havia madeira disponível. O veículo era todo nesse material e possuía uma cobertura em couro ou tecido preso a algum tipo de cana. $O$ sebo lubrificava os eixos e as rodas ${ }^{95}$. Uma "viagem redonda" (Buenos Aires - Jujuy) levava quase um ano, percorrendo cerca de sete léguas diárias. A vida útil dessas carretas era de cerca de dois anos. De modo geral, evitavam-se as viagens ao longo do dia. $\bigcirc$ sol fadigava os bois. Assim, viajava-se até às 10 da manhã, quando se montava acampamento até às 16 horas. Parava-se novamente para cear e, em boas condições climáticas e lua clara, viajava-se à noite ${ }^{96}$. É difícil precisar o início do uso das carretas no caminho, mas é seguro afirmar que já em 1587 elas percorriam esse trajeto em verdadeiras caravanas ${ }^{97}$. Os dois relatos de viajantes que o percorreram no século XVII falam das carretas e de sua importância para o transporte das mercadorias. Lizárraga lembrava como o tempo de viagem era mesmo ditado pelo ritmo dos bois, cerca de quatro léguas diárias, pois mais do que isso os "bueyes pueden sofrir". As carretas eram puxadas por quatro bois no mínimo e elas viajavam em comboios, às vezes formados por dezenas delas. Acarette, que também viajou nelas em seu retorno do Alto Peru, considerou-as muito mais cômodas do que as mulas ${ }^{98}$.

Uma parte dessas carretas pertencia aos próprios encomenderos comerciantes, como o sevilhano Juan de Vergara, um dos grandes contrabandistas de Buenos Aires que legou, em seu testamento, carretas, bois carreteros e madeira para a feitura desses veículos. Mas a maior parte estava nas mãos dos chamados fletadores, que transportavam as cargas em troca dos fretes. Acredita-se que, em Buenos Aires, cerca de 50\% das carretas estivessem nas mãos destes comerciantes fletadores, alguns organizados em verdadeiras companhias. A carreta que transportou as imagens entre Buenos Aires e Córdoba era, nesse sentido, um desses tradicionais veículos que circulavam continuamente pela afamada rota e pode ter pertencido tanto a um dos envolvidos na trama comercial, quanto a algum fretador.

Por esses caminhos, as duas pequenas e rústicas imagens em terracota da Virgem, oriundas das partes do Brasil, circularam em carretas e mulas, perfazendo trajetórias profundamente atreladas às redes de relações entre proprietários de estâncias, comerciantes, capitães de navios e gente envolvida em contrabando. Nestas conexões, entrevistas aqui em fragmentos de documentação e bibliografia, revela-se o intercâmbio entre uma vila considerada marginal nos quadros da circulação comercial do império português, com o porto de Buenos Aires e, portanto, com as ramificações nas redes de comércio platinas. Tais conexões atingiam produtos e gêneros de necessidade, como arroz, açúcar, marmelada e até mesmo escravos, mas atingia também produtos de devoção, como as imagens da Virgem Maria, apresentadas aqui.
94. Ver Raúl Mandrini (2012). A respeito da controvertida figura de Pedro Bohorquez, ver Teresa Piossek Prebisch (1976).

95. Reginaldo de Lizárraga (1916, p. 230) fala de como percorreram todo os pampas em carretas "las cualles no llevan una puenta de hierro".

96. Ver Guillermo Furlong (1969).

97. Além do caso do governador Velasco que presenciou o carregamento do bispo Vitória, Carlos Assadourian (1966, p.1) cita uma declaração em Córdoba, de 1587, na qual as duas testemunhas falam de como no "dia de hoy ban $\mathrm{y}$ bienen muchas carretas y mercadorias y plata desde esta dicha ciudad a la Buenos Aires".

98. Ver Reginaldo de Lizárraga (1916) e Acarette du Biscay (2014). 
Dessa forma, diversas partes da América lusitana se integraram à América espanhola por meio de redes comerciais, clientelare e familiares erguidas sobre caminhos terrestres, marítimos e fluviais. Nestas, o papel dos portugueses foi proeminente, funcionando muitas vezes como o veículo transmissor de mercadorias e objetos. Em 1630, em meio aos conflitos entre o governador do Rio da Prata com a poderosa rede de Juan de Vegara; dos olhares vigilantes e desconfiados da Inquisição sobre os portugueses; e da turbulenta revolta indígena do Valle Calchaquíes, duas imagens de terracota, provavelmente originárias das mãos de artesãos instalados na Capitania de São Vicente, chegaram às terras platinas enredadas em relações de comércio e amizade, e contrabando, para cumprir uma longa trajetória no universo do sagrado.

\section{REFERÊNCIAS}

AGUIRRE, Carlos Federico Ibarguren. Gonzales Filiano. Genealogia. Revista del Instituto Argentino de Ciencias Genealogicas, Buenos Aires, n. 17, p. 113-120, 1977.

ALCÂNTARA, Ailton S. de. Paulistinhas: imagens sacras, singelas e singulares. 2008. $131 \mathrm{f}$. Dissertação (Mestrado) - Universidade Estadual Paulista, Instituto de Artes, São Paulo, 2008.

AMARAL, Aracy Abreu. A hispanidade em São Paulo: da casa rural à Capela de Santo Antônio. São Paulo: Nobel, 1981.

APPADURAI, Arjun (Org.). A vida social das coisas: as mercadorias sob uma perspectiva cultural. Niterói: Eduff, 2009.

ARECES, Nidia R. TARRAGÓ, Griselda. La élite santafesina y los inmigrantes portugueses. In: ARECES, Nidia (Comp.). Poder y sociedad. Santa Fe la vieja: 1573-1660. Rosario: Prohistoria, 1999.

ASSADOURIAN, Carlos Sempat. El sistema de la economia colonial: el mercado interior, regiones y espacio económico. México: Nueva Imagem, 1983.

El tráfico de esclavos en Córdoba: 1588-1610. Córdoba: Universidad Nacional de Córdoba. Instituto de Estudios Americanistas. 1965.

El tráfico de esclavos en Córdoba de Angola a Potosí: siglos XVI-XVI. Córdoba: Dirección General de Publicaciones, 1966.

BISCAY, Acarette du. Relación de un viaje al Río de la Plata y de allí por tierra al Perú. Buenos Aires: Editorial Claridad, 2014.

BOMCHIL, Sara; CARREÑO, Virginia. El mueble colonial de las Americas y su circunstancia histórica. Tomo I. Buenos Aires: Maizal, 2011.

BOXER, Charles Ralph. Salvador de Sá e a luta pelo Brasil e Angola: 1602-1686. São Paulo: Nacional; Edusp, 1973. 
CALDEIRA, Jorge. Mulheres no caminho do Prata. São Paulo: Mameluco, 2006.

CALVO, Luis María. Pobladores españoles de Santa Fe la Vieja: 1573-1660. Buenos Aires: Academia Nacional de la Historia, 1999.

CANABRAVA. Alice Piffer. O comércio português no rio da Prata: 1580-1640. Belo Horizonte: Itatiaia; São Paulo: Edusp, 1984.

CARDIM, Pedro. De la nación a la lealtad al rey. Lourenço de Mendonça y el estatuto de los portugueses en la monarquía española de la década de 1630. In: CRUZ, David González (Org.). Extranjeros y enemigos en Iberoamérica: la visión del otro: del Imperio Español a la Guerra de la Independencia. Madrid, Sílex, 2010; p. 57-88.

CEBALLOS, Rodrigo. Arribadas portuguesas: a participação luso-brasileira na constituição social de Buenos Aires (c.1580-c.1680). 2007. 292f. Tese (Doutorado) - Instituto de Ciências Humanas e Filosofia da Universidade Federal Fluminense, Niterói, 2008.

Os vecinos lusitanos na restauração portuguesa: um estudo das redes sociais na Buenos Aires seiscentista. Métis: História \& Cultura, v. 13, n. 25, p. 31-57; jan./jun. 2014.

CORTABARRÍA, Jorge Juan. Juan María Gutiérrez y la historia de la Virgen de Luján. Anuario de Historia de la Iglesia, Pamplona, v. 16, p. 401-403, 2007.

ETZEL, Eduardo. Imagens religiosas de São Paulo. São Paulo: Melhoramentos, 1971.

FERREIRA, José Lélio Mendes. Maria na América. Bragança Paulista: A \& B, 1992.

FRADKIN, Raúl; GARAVAGLIA, Juan Carlos. La Argentina colonial: el Río de la Plata entre los siglos XVI y XIX. Buenos Aires: Siglo Veintiuno, 2009.

FURLONG, Guillermo. Historia social y cultural del Río de La Plata: 1536-1810.Buenos Aires: Tipográfica Editora Argentina, 1969. 3 v.

GARAVAGLIA, Juan Carlos. Mercado interno y economía colonial: tres siglos de historia de la yerba mate. Rosario: Prohistoria, 2008.

GELMAN, Jorge Daniel. Cabildo y elite local: el caso de Buenos Aires en el siglo XVII. HISLA - Revista Latinoamericana de Historia Económica y Social, Lima, n. 6, p. 3-20, 1985.

GOLLÁN, Agustín Zapata. Portugueses en Santa Fe la Vieja. Academia Nacional de História: Buenos Aires, 1970.

GOULÃO, Maria José. Ourivesaria luso-brasileira no Rio da Prata. Oceanos, Lisboa, n. 4, p. 37- 42, 1990.

GRUZINSKI, Serge. As quatro partes do mundo: história de uma mundialização. Belo Horizonte: UFMG; São Paulo: Edusp, 2014.

HELMER, Marie. Comércio e contrabando entre a Bahia e Potosi no século XVI. Revista de História, São Paulo, v. 7, n. 15, jul./set. 1953. 
HERZOG, Tamar. Defining Nations. Immigrants and Citizens in Early Modern Spain and Spanish America. New Haven; Londres: Yale Univesity Press, 2003.

HOLANDA, Sérgio Buarque. Caminhos e fronteiras. São Paulo: Companhia das Letras, 1994.

Inventários e testamentos. v. 1 a 48. São Paulo: Departamento do Arquivo do Estado de São Paulo (Daesp).

JENSEN, Carlos Romero. Los Bogado y el aporte portugués al Paraguay. História Paraguaya. Anuario de la Academia Paraguaya de la Historia, Assunção, v. XLVII, 2007.

KOPYTOFF, Igor. A biografia cultural das coisas: a mercantilização como processo. In: APPADURAI, Arjun (Org.). A vida social das coisas: as mercadorias sob uma perspectiva cultural. Niterói: Eduff, 2009.

LEBRERO, Rodolfo E. González. La pequeña aldea: sociedad y economía en Buenos Aires: 1580-1640. Buenos Aires: Biblos; 2002. (Histórias Americanas).

LEMOS, Carlos Alberto Cerqueira. A imaginária paulista. São Paulo: Edições Pinacoteca, 1999.

Escultura colonial brasileira: panorama da imaginária paulista no século XVII. São Paulo: Kosmos, 1979.

LIZÁRRAGA, Frei Reginaldo de. Descripcion breve de toda la tierra del Perú, Tucumán, Río de la Plata y Chile. Noticia preliminar de Ricardo Rojas. Buenos Aires: Librería la Facultad de Juan Roldán, 1916.

MACHAIN, Ricardo de Lafuente. Los portugueses en Buenos Aires: siglo XVII. Buenos Aires: Tipografía de Archivos, 1931.

MANDRINI, Raúl. La Argentina aborigen. De los primeros pobladores a 1910. Buenos Aires: Siglo Veintiuno, 2012.

MARQUES, Manuel Eufrásio de Azevedo. Apontamentos históricos, geográficos, biográficos, estatísticos e noticiosos da província de São Paulo... São Paulo: Itatiaia, 1980.

MOLINA, Raúl Alejandro. Leyenda e historia de la Virgen de Luján, Boletín de la Academia Nacional de la Historia, Buenos Aires, n. 40, p. 151-197, 1967.

. Diccionario biográfico de Buenos Aires: 1580-1720. Buenos Aires: Academia Nacional de la Historia, 2000.

MONTEIRO, John Manuel. Negros da terra: índios e bandeirantes nas origens de São Paulo. São Paulo: Companhia das Letras, 1998.

MOTT, Luiz. Cotidiano e vivência religiosa: entre a capela e o calundu. In: SOUZA, Laura de Mello e (Ed.). História da vida privada no Brasil: cotidiano e vida privada na América portuguesa. São Paulo: Companhia das Letras, 1997.

MOUTOUKIAS, Zacarias. Familia patriarcal o redes sociales: balance de una imagen de la estratificación social. Anuario del IEHS, Tandil, n. 15, p. 133-151, 2000. 
MOUTOUKIAS, Zacarias. Contrabando y control colonial en el siglo XVII: Buenos Aires, el Atlántico y el Espacio Peruano. Buenos Aires: Centro Editor de América Latina, 1988.

PERUSSET, Macarena. Contrabando y sociedade en el Río de la Plata Colonial. Buenos Aires: Dunken, 2006.

PREBISCH, Teresa Piossek. La rebelión de Pedro Bohórquez, el inca del Tucumán: 1656-1659: Relato histórico-documental. Buenos Aires: Juárez, 1976.

PRESAS, Juan Antonio. Doña Ana de Matos: (la dama que con la Virgen fundó a Luján): 16151698. Morón: Universidad de Morón, 1990.

Nuestra Señora en Luján y Sumampa. Estudio crítico-histórico: 1630-1730. Buenos Aires: Ediciones Autores Asociados Morón, 1974.

. Anales de Nuestra Señora de Luján: trabajo histórico-documental: 1630-2002. Buenos Aires: Editorial Dunken, 2002.

ROBERTO, Francisco. É paulista a imagem de Nossa Senhora de Luján, padroeira da Argentina?. Revista do Instituto Histórico e Geográfico Guarujá-Bertioga, n. 11, 1978.

SALVADOR, José Gonçalves. Os cristãos novos e o comércio no Atlântico Meridional. São Paulo: Pioneira, 1978.

SILVA-NIGRA, Dom Clemente Maria da. Os dois escultores, frei Agostinho da Piedade, frei Agostinbo de Jesus, e o arquiteto frei Macário de São João. Salvador: UFB, 1971.

SOUZA, Juliana Beatriz Almeida de. Virgem mestiça: devoção à Nossa Senhora na colonização do Novo Mundo. Tempo, Revista do Departamento de História da UFF, Niterói, v. 6, n. 11, p. 77-92, 2001.

STELLA, Roseli Santaella. Sobre a capitania de São Vicente: séc. XVI-XVII. São Paulo: Academia Lusíada de Ciências, Letras e Artes, 1999.

TIRAPELI, Percival. Igrejas paulistas: barroco e rococó. São Paulo: Imprensa Oficial; Unesp, 2003.

UGARTE, Rubén Vargas. Historia del culto de Maria en Iberoamérica y de sus imágenes y santuarios más celebrados. Buenos Aires: Huarpes, 1956.

VENTURA, Maria da Graça A. Mateus. Portugueses no Peru ao tempo da União Ibérica: mobilidade, cumplicidades e vivências. v. I e II. Lisboa: Imprensa Nacional-Casa da Moeda, 2005.

VILARDAGA, José Carlos. São Paulo no império dos Felipes: conexões na América Meridional: 1580-1640. São Paulo: Editora Intermeios, 2014.

YAO, Jean-Arsène. La trata de los negros en el Río de la Plata: restricciones legales y contrabando en la época colonial. In: PINEAU, Marisa (Ed.). La ruta del esclavo en el Río de la Plata: aportes para el diálogo intercultural. Bueno Aires: Caseros, 2011.

Artigo apresentado em 12/08/2015. Aprovado em 02/11/2015.

Annals of Museu Paulista. v. 23. n.2. Jul.-Dec. 2015. 